Comparison of statistical models for estimation of methane emission in dairy Simmentals based on animal recording data

Usporedba statističkih modela za procjenu emisije metana mliječnih simentalskih krava temeljem podataka kontrole proizvodnosti

Gantner, V., Gavran, M., Kuterovac, K., Gregić, M., Vučković, G., Gantner, R.

Poljoprivreda/Agriculture

ISSN: $1848-8080$ (Online)

ISSN: 1330-7142 (Print)

http://dx.doi.org/10.18047/poljo.25.1.11

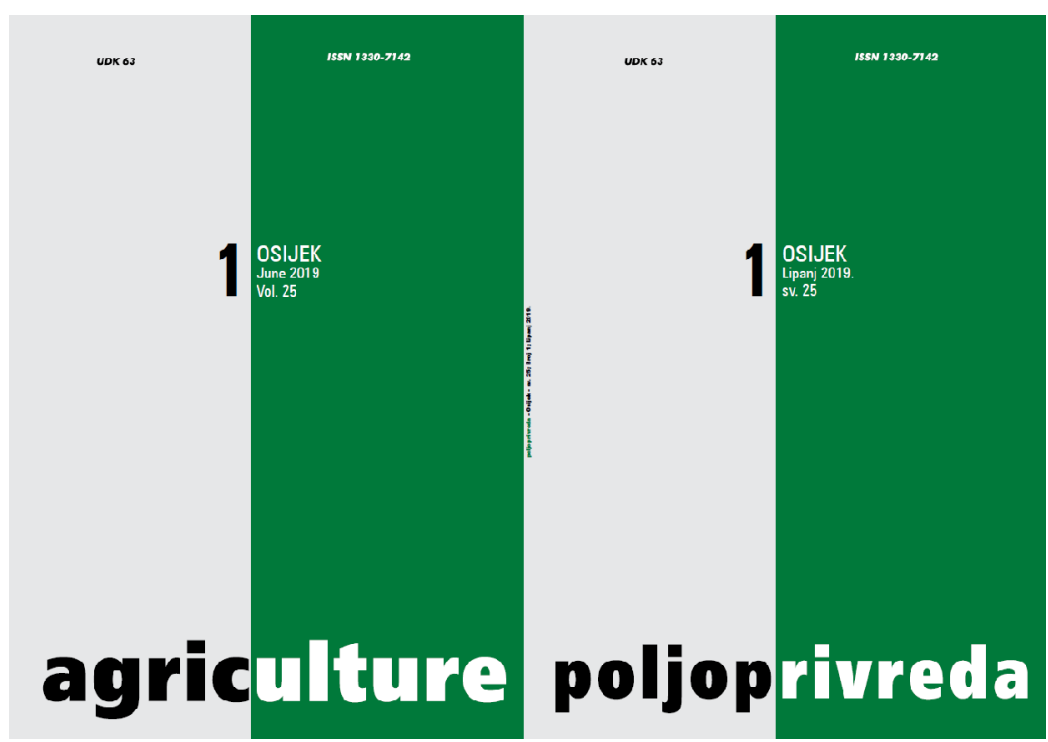

Fakultet agrobiotehničkih znanosti Osijek, Poljoprivredni institut Osijek

Faculty of Agrobiotechnical Sciences Osijek, Agricultural Institute Osijek 


\title{
COMPARISON OF STATISTICAL MODELS FOR ESTIMATION OF METHANE EMISSION IN DAIRY SIMMENTALS BASED ON ANIMAL RECORDING DATA
}

Gantner, V.(1), Gavran, M. ${ }^{(1)}$, Kuterovac, K. ${ }^{(2)}$, Gregić, M. ${ }^{(1)}$, Vučković, G. ${ }^{(1)}$, Gantner, R. ${ }^{(1)}$

Original scientific paper

Izvorni znanstveni članak

\begin{abstract}
SUMMARY
In the last decades we have witnessed increasingly pronounced climate change worldwide resulting in environment transformation in various regions by making it not convenient for agricultural and livestock production. The global livestock sector contributes to anthropogenic greenhouse gas emission, but on the other hand, it can also deliver a significant share of the necessary mitigation effort. One of the most significant greenhouse gas is methane. Mitigation methods for the methane emissions in cattle can be classified as short and long term. Short-term methods imply increase of production per animal, reduction of number of animals and feeding optimization, while long-term methods imply genetic evaluation and selection based on methane emission variation. Prerequisite for genetic evaluation is selection of optimal indicators and models with high accuracy and easy applicability in routine Animal Recording. Therefore, the objective of this study was to evaluate different models for methane emission estimation in dairy cows based on Animal Recording data. The results obtained indicate that data from regular Animal Recording could be used in estimation of methane emission of dairy Simmental cows enabling the population analysis and genetic evaluation of dairy cattle for methane emission. Given the very high variability determined in estimated methane emission values regarding the used statistical models and aiming high accuracy of genetic evaluation it is recommended to define estimation models for body weight dry matter intake and methane emission based on parameters (type traits and testday records) of particular dairy cattle population. The stated will enable genetic evaluation of dairy cattle for methane emission as well as selection of cows with lower methane emission intensity. Finally, this will lead to environmentally sustainable milk production.
\end{abstract}

Key words: methane emission, estimation, statistical models, dairy Simmentals, animal recording

\section{INTRODUCTION}

The changes of climate according to the predictions (IPCC, 2007) become imminent and will have great impact on animal production worldwide. Battisti and Naylor (2009) stated that by 2050, most of the world will experience median temperatures in the summer warmer than the warmest temperatures recorded (period from 1900 to 2006). Peltonen-Sainio et al. (2010) indicated an increasing trend towards the systematic warming of the Earth's climate, particularly Europe, while Trnka et al. (2011) estimated that by 2050 air

(1) Prof. Vesna Gantner, Ph.D., Mirna Gavran, M. Eng. Agr. (mirna.gavran@ gmail.com), Maja Gregić, Ph.D., Assoc. Prof. Ranko Gantner, Ph.D. - Josip Juraj Strossmayer University of Osijek, Faculty of Agrobiotechnical Sciences Osijek, V. Preloga 1, 31000 Osijek, Croatia, (2) Krešimir Kuterovac - Inagra Ltd., Strossmayerova 341, 31000 Osijek, Croatia, (3) Goran Vučković - Rinderunion Baden-Württemberg, Ölkofer Strasse 41, 88518 Herbertingen, Germany 
temperature may rise by as much as $2^{\circ} \mathrm{C}$. Furthermore, Gauly et al. (2013) stated that in the global warming scenarios, the heat stress of high-producing dairy cows will be an increasing concern of milk producers in Europe. Segnalini et al. (2013) emphasized the necessity of appropriate adaptation strategies development in order to minimize the negative effects of warming in farm animals in the Mediterranean basin. Regarding Europe, GIRA - Consultancy and Research Prospective and Strategie (2012), in the analysis of Regional movements in EU Milk Production, forecasts the movement from regions with intensive farming towards regions around the Atlantic with less intensive farming and more land suitable for pasture (i.e. lower production costs). Currently, agriculture plays an important role in global environmental issues, such as: climate change, land degradation, water pollution and biodiversity loss (FA0, 2013). Also, there is a common opinion that the global animal production sector, particularly cattle production systems, significantly contribute to an anthropogenic greenhouse gas (GHG) emissions (Mosnier et al., 2017). It is estimated that total GHG emissions from livestock supply chains represents $14.5 \%$ of all anthropogenic emissions (IPCC, 2007). Regarding the species, cattle are the main contributor to the sector's emissions with about $65 \%$ (about $30 \%$ comes from milk production, FAO, 2013). One of the most significant greenhouse gases, highly correlated with global warming is methane $\left(1 \mathrm{~g} \mathrm{CH}_{4}\right.$ heats the atmosphere 21 times more than $1 \mathrm{~g} \mathrm{CO}_{2}$ ); about $44 \%$ of all greenhouse gasses from livestock sector (FA0, 2013). The global livestock sector can also deliver a significant share of the necessary mitigation effort. Methods for the methane emission reduction in cattle can be classified as short and long term. Short-term methods imply increase of production per animal (consequently decreasing the number of animals needed to produce equal amounts of animal products) and feeding optimization, while longterm methods imply genetic evaluation and selection based on methane emission variation. A prerequisite for genetic evaluation for methane emission is selection of optimal indicators and models that should be highly accurate and easy applicable in routine Animal
Recording. There are many methods for estimation of methane emission that could be characterized as direct and indirect measures (Cassandro et al., 2013). The gold standard to measure methane and GHG emissions is the respiratory chamber. Since this technique is time consuming and costly, i.e. requires a large number of measurements, it cannot be used for genetic evaluation. The methane emission can also be estimated based on feed intake records (Kriss, 1930; Axelsson, 1949; Mills et al., 2003; Ellis et al., 2010; Nielsen et al., 2013), breath analysis and cow exterior characteristics and milk composition records (Cassandro et al., 2013). Milk Recording and Type Traits evaluation are routinely performed in dairy cattle population, the objective of this study was to evaluate different models for estimation of methane emission in dairy Simmentals based on Animal Recording data.

\section{MATERIAL AND METHODS}

Dataset containing type traits records of the first parity dairy Simmentals scored from 1997 till 2017 by the field officers of the Croatian Agricultural Agency was used for statistical analysis. After logical control dataset contained 15,143 records. The following variables were used as indicators for methane emission estimation:

- Body weight (BW),

- Dry matter intake (DMI).

BW was calculated from type traits records as follows:

Body weight $(\mathrm{kg})=$ heart girth $(\mathrm{cm}) \times$ body length (cm) / 50 (Brem, 1998)

Body length $(\mathrm{cm})=$ rump length $(\mathrm{cm})+$ back length $(\mathrm{cm})$

DMI was calculated using following equation:

DMl $(\mathrm{kg} / \mathrm{d})=12.91 \times\left[1-\mathrm{e}^{(-0.00295 \times \mathrm{BW})}\right]($ Hoffman et al., 2008).

The variability of the used type traits (heart girth, rump length and back length) as well as indicators (body weight and dry matter intake) for methane emission estimation is shown in Table 1.

Table 1. Variability of type traits and indicators for methane emission estimation $(n=15,143)$.

Tablica 1. Varijabilnost svojstava eksterijera te indikatora procjene emisije metana ( $n=15.143)$.

\begin{tabular}{|l|r|r|r|r|r|}
\hline Trait/Svojstvo & Mean & SD & CV & Min & Max \\
\hline Hearth girth (cm) & 193.55 & 9.39 & 4.85 & 159.00 & 225.00 \\
Rump length (cm) & 51.82 & 2.69 & 5.18 & 39.00 & 65.00 \\
Back length (cm) & 87.92 & 5.09 & 5.79 & 70.00 & 110.00 \\
Body weight (kg) & 543.85 & 44.15 & 8.12 & 384.00 & 724.88 \\
DMl (kg/d) & 10.29 & 0.34 & 3.28 & 8.75 & 11.39 \\
\hline
\end{tabular}

DMI - dry matter intake 
The following statistical models for methane emission estimation of dairy Simmental cows based on the calculated DMI were used:

- $\mathrm{M} 1 . \mathrm{CH}_{4}(\mathrm{MJ} / \mathrm{d})=75.42+94.28 \times \mathrm{DMI}$ $(\mathrm{kg} / \mathrm{d}) \times 0.05524\left(\mathrm{MJ} / \mathrm{g}\right.$ of $\left.\mathrm{CH}_{4}\right)($ Kriss, 1930),

- $\mathrm{M} 2 . \mathrm{CH}_{4}(\mathrm{MJ} / \mathrm{d})=-2.07+2.636 \times \mathrm{DMI}$ $(\mathrm{kg} / \mathrm{d})-0.105 \times \mathrm{DMl}(\mathrm{kg} / \mathrm{d})^{2}$ (Axelsson, 1949)

- $\quad \mathrm{M} 3 . \mathrm{CH}_{4}(\mathrm{MJ} / \mathrm{d})=5.93+0.92 \times \mathrm{DMl}(\mathrm{kg} / \mathrm{d})$ (Mills et al., 2003),

- M4. $\mathrm{CH}_{4}(\mathrm{MJ} / \mathrm{d})=56.27-(56.27+0) \times$ $\mathrm{e}^{[-0.028 \times \mathrm{DMl}(\mathrm{kg} / \mathrm{d})]}$ (Mills et al., 2003),

- $\quad \mathrm{M} 5 . \mathrm{CH}_{4}(\mathrm{MJ} / \mathrm{d})=3.23( \pm 1.12)+0.809( \pm$ $0.0862) \times \mathrm{DMl}(\mathrm{kg} / \mathrm{d})$ (Ellis et al., 2010),

- $\quad \mathrm{M} 6 . \mathrm{CH}_{4}(\mathrm{MJ} / \mathrm{d})=3.272( \pm 0.794)+0.736$ $( \pm 0.0741) \times \mathrm{DMl}(\mathrm{kg} / \mathrm{d})$ (Ellis et al., 2010),

- M7. $\mathrm{CH}_{4}(\mathrm{MJ} / \mathrm{d})=1.26( \pm 0.03) \times \mathrm{DMI}$ (Nielsen et al., 2013).
SAS/STAT (SAS Institute Inc., 2000) was used for preparation of data and statistical analysis. The variability of estimated methane emission due to used statistical model was determined by least square analyses of variance using the PROC GLM procedure. The significance of the differences between the used statistical models was tested by Scheffe's method of multiple comparisons.

\section{RESULTS AND DISCUSSION}

The variability of the estimated methane emission $\left(\mathrm{CH}_{4}, \mathrm{MJ} / \mathrm{d}\right)$ using seven different statistical models (M1-M7) is presented in Table 2. The lowest methane emission on the average amount of $10.85 \mathrm{MJ} / \mathrm{d}$ was estimated using statistical model $6(\mathrm{M} 6)$, while the highest emission on the average amount of 129.03 $\mathrm{MJ} / \mathrm{d}$ was estimated using model 1 (M1).

Table 2. Variability of estimated methane emission $\left(\mathrm{CH}_{4}, \mathrm{MJ} / \mathrm{d}\right)$ using seven different statistical models (M1-M7) for estimation $(n=15,143)$.

Tablica 2. Varijabilnost emisije metana (CH4, MJ/d) procijenjene uporabom sedam različitih statističkih modela (M1-M7) za procjenu $(n=15.143)$.

\begin{tabular}{|c|c|c|c|c|c|}
\hline $\begin{array}{c}\text { Statistical model } \\
\text { Statistički model }\end{array}$ & Mean & SD & CV & Min \\
\hline M1 & $129.03^{\mathrm{A}}$ & 1.76 & 1.36 & 120.99 \\
M2 & $13.93^{\mathrm{B}}$ & 0.16 & 1.17 & 12.96 & 13.98 \\
M3 & $15.40^{\mathrm{C}}$ & 0.31 & 2.02 & 13.33 \\
M4 & $14.09^{\mathrm{D}}$ & 0.39 & 2.83 & 12.23 \\
M5 & $11.56^{\mathrm{E}}$ & 0.27 & 2.36 & 10.31 \\
M6 & $10.85^{\mathrm{F}}$ & 0.25 & 2.29 & 12.36 \\
M7 & $12.97^{\mathrm{G}}$ & 0.43 & 3.28 & 11.65 \\
\end{tabular}

Values within the same column marked with different letter differ statistically highly significant $(P<0.001)$

The analysis of variance of estimated methane emissions showed statistically highly significant $(P<0.001)$ effect of the used statistical model for estimation (M1-M7). Furthermore, Scheffe's test showed that statistically highly significant $(P<0.001)$ difference in methane emission existed between all the tested statistical models (M1-M7, Table 2).

It is frequent opinion that livestock sector, especially ruminant production systems, contributes significantly to climate change by emitting GHG. The GHG could be emitted directly from animals (enteric fermentation) or indirectly by feed production, manure management, etc. For instance, Cassandro et al. (2013) stated that ruminants, mainly by enteric fermentation (about $95 \%$ ), produce approximately 250 to $500 \mathrm{~L}$ of $\mathrm{CH}_{4}$ /day. Murray et al. (1976) found out that in ruminants, enteric methane is produced mainly in the rumen $(87 \%)$, while the rest $(13 \%)$ is produced in the large intestine. McAllister and Newbold (2008) determined that the enteric methane is produced in anaerobic conditions by methanogenic archaea using carbon dioxide and hydrogen, and consequently form the methane. Several studies (Beauchemin et al., 2008; McAllister and Newbold, 2008; Martin et al., 2010) analyzed possibilities of feed management and microbial manipulation in order to reduce enteric methane emissions from livestock sector. Furthermore, several studies (Herd et al., 2002; Hegarty et al., 2007; Cassandro et al., 2010; Cassandro, 2013) determined variation in enteric methane emission between breeds and individual animals enabling possibility for genetic evaluation and selection of animals with lower emission. Aiming to apply this long-term method of methane reduction in routine at state level, optimal indicators and models with high accuracy and applicability need to be defined. Results of this study indicated high variability in estimated methane emission due to the used statistical model. Also, a number of studies (Elis et al., 2007; Nielson et al., 2013) showed great variability in 
estimated methane emission (4.12-22.3 $\mathrm{MJ} / \mathrm{d})$ in regard to collection technique (whole animal calorimetry, or $\mathrm{SF}_{6}$ ) or estimation model.

Due to the high variability in the estimated methane emissions and aiming successful implementation of proper mitigation options it is necessary to develop estimation models based on parameters of particular dairy cattle population.

\section{CONCLUSION}

Obtained results indicate that data from regular Animal Recording could be used in estimation of methane emission of dairy Simmental cows enabling the population analysis and genetic evaluation of dairy cattle for methane emission. Given the determined very high variability in estimated methane emission values regarding the used statistical models and aiming high accuracy of genetic evaluation it is recommended to define estimation models for BW, DMI and methane emission based on parameters (type traits and test-day records) of particular dairy cattle population. The stated will enable genetic evaluation of dairy cattle for methane emission as well as selection of cows with lower methane emission intensity. Finally, this will lead to environmentally sustainable milk production.

\section{ACKNOWLEDGEMENTS}

The authors gratefully acknowledge the support of the Croatian Agricultural Agency who provided necessary Animal Recording data.

\section{REFERENCES}

1. Axelsson, J. (1949). The amount of produced methane energy in the European metabolic experiments with adult cattle. Kungliga Lantbrukshogskolans Annaler, 16, 404-419.

2. Battisti, D. S., \& Naylor, R. L. (2009). Historical warnings of future food insecurity with unprecedented seasonal heat. Science, 323(5911), 240-244.

https://doi.org/10.1126/science.1164363

3. Beauchemin, K. A., Kreuzer, M., O'mara, F., \& McAllister, T. A. (2008). Nutritional management for enteric methane abatement: a review. Australian Journal of Experimental Agriculture, 48(2), 21-27. https://doi.org/10.1071/EA07199

4. Brem, G. (Ed.). (1998). Exterieurbeurteilung landwirtschaftlicher Nutztiere. Ulmer.

5. Cassandro, M., Cecchinato, A., Battagin, M., \& Penasa, M. (2010, August). Genetic parameters of methane production in Holstein Friesian cows. In Proceeding of the 9th World Congress on Genetics Applied to Livestock Production (WCGALP), 1-6 August 2010, Leipzig, Germany.

6. Cassandro, M. (2013). Comparing local and cosmopolitan cattle breeds on added values for milk and cheese production and their predicted methane emissions. Animal Genetic Resources/Resources génétiques
animales/Recursos genéticos animales, 53, 129-134. https://doi.org/10.1017/S207863361200077X

7. Cassandro, M., Mele, M., \& Stefanon, B. (2013). Genetic aspects of enteric methane emission in livestock ruminants. Italian Journal of Animal Science, 12(3), 450-458. https://doi.org/10.4081/ijas.2013.e73

8. Ellis, J. L., Kebreab, E., Odongo, N. E., McBride, B. W., Okine, E. K., \& France, J. (2007). Prediction of methane production from dairy and beef cattle. Journal of Dairy Science, 90(7), 3456-3466. https://doi.org/10.3168/jds.2006-675

9. Ellis, J. L., Bannink, A., France, J., Kebreab, E., \& Dijkstra, J. (2010). Evaluation of enteric methane prediction equations for dairy cows used in whole farm models. Global Change Biology, 16(12), 3246-3256. https:// doi.org/10.1111/j.1365-2486.2010.02188.x

10. Gerber, P. J., Steinfeld, H., Henderson, B., Mottet, A., Opio, C., Dijkman, J., ... \& Tempio, G. (2013). Tackling climate change through livestock: a global assessment of emissions and mitigation opportunities. Food and Agriculture Organization of the United Nations (FAO). https://doi.org/10.3168/jds.2006-675

11. Gauly, M., Bollwein, H., Breves, G., Brügemann, K., Dänicke, S., Daş, G., ... \& Lohölter, M. (2013). Future consequences and challenges for dairy cow production systems arising from climate change in Central Europe-a review. Animal, 7(5), 843-859. https://doi.org/10.1017/S1751731112002352

12. GIRA - Consultancy and Research Prospective and Strategie (2012). World and EU dairy through 2016. GIRA Consultancy \& Research Prospective et Strategie, France, 5-21. http://ec.europa.eu/agriculture/milk/background/jm-2012-12-12/01-gira_en.pdf

13. Hegarty, R. S., Goopy, J. P., Herd, R. M., \& McCorkell, B. (2007). Cattle selected for lower residual feed intake have reduced daily methane production. Journal of Animal Science, 85(6), 1479-1486.

https://doi.org/10.2527/jas.2006-236

14. Herd, R. M., Arthur, P. F., Hegarty, R. S., \& Archer, J. A. (2002, August). Potential to reduce greenhouse gas emissions from beef production by selection for reduced residual feed intake. In Proceedings of the 7th World Congress on Genetics Applied to Livestock Production'. Communication (No. 10-22).

15. Hoffman, P. C., Weigel, K. A., \& Wernberg, R. M. (2008). Evaluation of equations to predict dry matter intake of dairy heifers. Journal of Dairy Science, 91(9), 36993709. https://doi.org/10.3168/jds.2007-0644

16. Change, I. C. (2007). The physical science basis. Contribution of working group I to the Fourth Assessment Report of the Intergovernmental Panel on Climate Change, 996.

17. Kriss, M. (1930). Quantitative relations of the dry matter of the food consumed, the heat production, the gaseous outgo, and the insensible loss in body weight of cattle. Journal of Agricultural Research, 40(3), 283-295.

18. Martin, C., Morgavi, D. P., \& Doreau, M. (2010). Methane mitigation in ruminants: from microbe to the farm scale. Animal, 4(3), 351-365.

https://doi.org/10.1017/S1751731109990620 
19. McAllister, T. A., \& Newbold, C. J. (2008). Redirecting rumen fermentation to reduce methanogenesis. Australian Journal of Experimental Agriculture, 48(2), 7-13. https://doi.org/10.1071/EA07218

20. Mills, J. A. N., Kebreab, E., Yates, C. M., Crompton, L. A., Cammell, S. B., Dhanoa, M. S., ... \& France, J. (2003). Alternative approaches to predicting methane emissions from dairy cows. Journal of Animal Science, 81(12), 3141-3150. https://doi.org/10.2527/2003.81123141x

21. Mosnier, C., Duclos, A., Agabriel, J., \& Gac, A. (2017). What prospective scenarios for 2035 will be compatible with reduced impact of French beef and dairy farm on climate change? Agricultural Systems, 157, 193-201. https://doi.org/10.1016/j.agsy.2017.07.006

22. Murray, R. M., Bryant, A. M., \& Leng, R. A. (1976). Rates of production of methane in the rumen and large intestine of sheep. British Journal of Nutrition, 36(1), 1-14. https://doi.org/10.1079/BJN19760053

23. Nielsen, N. I., Volden, H., Åkerlind, M., Brask, M., Hellwing, A. L. F., Storlien, T., \& Bertilsson, J. (2013).
A prediction equation for enteric methane emission from dairy cows for use in NorFor. Acta Agriculturae Scandinavica, Section A-Animal Science, 63(3), 126130. https://doi.org/10.1080/09064702.2013.851275

24. Peltonen-Sainio, P., Jauhiainen, L., Trnka, M., Olesen, J. E., Calanca, P., Eckersten, H., ... \& Kumar, S. (2010). Coincidence of variation in yield and climate in Europe. Agriculture, Ecosystems \& Environment, 139(4), 483-489. https://doi.org/10.1016/j.agee.2010.09.006

25. Segnalini, M., Bernabucci, U., Vitali, A., Nardone, A., \& Lacetera, N. (2013). Temperature humidity index scenarios in the Mediterranean basin. International Journal of Biometeorology, 57(3), 451-458.

https://doi.org/10.1007/s00484-012-0571-5

26. Trnka, M., Olesen, J. E., Kersebaum, K. C., Skjelvåg, A. 0., Eitzinger, J., Seguin, B., ... \& Dubrovský, M. (2011). Agroclimatic conditions in Europe under climate change. Global Change Biology, 17(7), 2298-2318. https://doi.org/10.1111/j.1365-2486.2011.02396.x

\section{USPOREDBA STATISTIČKIH MODELA ZA PROCJENU EMISIJE METANA MLIJEČNIH SIMENTALSKIH KRAVA TEMELJEM PODATAKA KONTROLE PROIZVODNOSTI}

\section{SAŽETAK}

Posljednjih desetljeća svjedočimo sve izraženijim klimatskim promjenama diljem svijeta, koje su rezultirale preobrazbom okoliša u različitim regijama čineći ga nepogodnim za poljoprivrednu, a osobito za stočarsku proizvodnju. Globalni stočarski sektor značajno doprinosi antropogenoj emisiji stakleničkih plinova, no, s druge strane, također može značajno doprinijeti mjerama ublažavanja. Jedan od najznačajnijih stakleničkih plinova je metan. Metode ublažavanja emisija metana u goveda mogu se klasificirati kao kratkoročne i dugoročne. Kratkoročne metode podrazumijevaju povećanje proizvodnje po životinji, smanjenje broja životinja i optimizaciju hranidbe, dok dugoročne metode podrazumijevaju genetsku evaluaciju i selekciju na temelju varijacija u emisiji metana. Preduvjet za genetsku evaluaciju je izbor optimalnih indikatora i modela koji su vrlo točni i lako primjenjivi u rutinskoj kontroli proizvodnosti. Cilj ovoga istraživanja bio je procijeniti različite modele za procjenu emisije metana u mliječnih krava na temelju podataka kontrole proizvodnosti. Dobiveni rezultati upućuju na to da bi se podatci kontrole proizvodnosti mogli koristiti za procjenu emisije metana kod mliječnih simentalskih krava, što omogućuje analizu populacije i genetsku evaluaciju mliječnih goveda za emisiju metana. S obzirom na utvrđenu vrlo visoku varijabilnost u procijenjenim vrijednostima emisije metana u odnosu na korišteni statistički model te s ciljem visoke točnosti genetske evaluacije, preporučuje se definiranje modela procjene tjelesne mase, unosa suhe tvari i emisije metana na temelju parametara locjene eksterijera te zapisi na kontrolni dan) populacije pojedinih mliječnih goveda. Model će omogućiti genetsku evaluaciju mliječnih goveda za emisiju metana, kao i selekciju krava s manjom emisijom metana. Primjena navedenoga u konačnici će dovesti do ekološki prihvatljivije proizvodnje mlijeka.

Ključne riječi: emisija metana, procjena, statistički modeli, mliječne simentalske krave, kontrola proizvodnosti

(Received on December 13, 2018; accepted on April 18, 2019 - Primljeno 13. prosinca 2018.; prihvaćeno 18. travnja 2019.) 